\title{
Penerapan Multimedia Interaktif Mind Mapping Untuk Meningkatkan Motivasi Belajar Siswa Dalam Pembelajaran Pendidikan Agama Islam
}

\author{
Erika Nurazizah, Yeti Nuraeni, Wahyudin, Fitriyantiny \\ Magister Pendidikan, Teknologi Pendidikan, Institut Pendidikan Indonesia \\ Email: edjoerye180409@gmail.com
}

\begin{abstract}
. to find out the effectiveness of using the mind mapping learning media model of mulasi compared to conventional classes in increasing student understanding of the subject of Islamic Religious Education (2) to find out students' responses to the use of multimedia learning mind mapping models. The research method used is descriptive analytic method, which is to analyze the picture that occurs at the time of the research, namely the study of the use of mind mapping learning models with interactive multimedia. The results showed that first the mind mapping learning method can improve the learning outcomes of Islamic religious education, second, the use of interactive multiedia can improve student learning outcomes, third, mind mapping learning and the use of interactive multimedia can improve student learning outcomes.
\end{abstract}

\section{Keywords: Interactive Multimedia, Mind Mapping, Learning Motivation}

Abstrak. (1) untuk mengetahui efektifitas penggunaan media pembelajaran model mind mapping mulasi dibandingkan dengan kelas konvensional dalam meningkatkan pemahaman siswa pada mata pelajaran Pendidikan Agama Islam (2) untuk mengetahui tanggapan peserta didik terhadap penggunaan multimedia pembelajaran model mind mapping. Metode penelitian yang digunakan adalah metode deskriptif analitik, yaitu menganalisis gambaran yang terjadi pada saat dilakukan penelitian, yakni kajian terhadap penggunaan Model Pembelajaran mind mapping dengan multimedia interaktif. Hasil penelitian menunjukkan bahwa pertama metode pembelajaran mind mapping dapat meningkatkan kemampuan hasil belajar pendidikan agama islam, kedua penggunaan multiedia interaktif dapat meningkatkan kemampuan hasil belajar siswa, ketiga pembelajaran mind mapping dan penggunaan multimedia interaktif dapat meningkatkan kemampuan hasil belajar siswa.

Kata Kunci: Multimedia Interaktif, Mind Mapping, Motivasi Belajar.

\section{PENDAHULUAN}

Kegiatan pendidikan di sekolah diwujudkan dalam pelaksanaan pembelajaran dikelas yang bertujuan untuk tercapainya perubahan perilaku atau kompetensi pada siswa setelah mengikuti kegiatan pembelajaran. Pembelajaran merupakan upaya atau proses untuk membelajarkan peserta didik. Guru memiliki peran yang penting dalam mencapai tujuan pembelajaran yang direalisasikan dengan merancang pembelajaran yang mencakup penggunaan metode mengajar, media pembelajaran, serta system evaluasi penilaian hasil belajar yang efektif dan efesien sesuai dengan kebutuhan dilapangan.

Sistem pembelajaran merupakan kesatuan komponen-komponen yang terlibat dalam pembelajaran guna mencapai tujuan tertentu. Dengan kata lain seluruh komponen dalam system pembelajaran diarahkan untuk mewujudkan tujuan pembelajaran yang telah ditetapkan.

Dalam suatu proses belajar mengajar, unsur yang sangat penting adalah kompetensi guru, metode mengajar dan media pembelajaran. Aspek-aspek tersebut saling berkaitan, karena pemilihan salah satu metode mengajar akan mempengaruhi jenis media pembelajaran yang digunakan, meskipun masih ada faktor lain yang harus diperhatikan dalam pemilihan media, diantaranya : tujuan pembelajaran, jenis tugas, dan respon yang dikuasai siswa setelah proses pembelajaran berlangsung, termasuk karakter siswa. Dengan demikian bahwa salah satu fungsi utama media pembelajaran sebagai alat bantu mengajar yang sangat mempengaruhi iklim, 
kondisi, dan lingkungan belajar yang diciptakan oleh guru. Penggunaan media pembelajaran dalam proses belajar mengajar dapat mengakibatkan keinginan dan minat yang baru, membangkitkan motivasi dan rangsangan dalam kegiatan belajar, bahkan membawa pengaruh psikologis terhadap siswa. Penggunaan media pembelajaran akan sangat membantu keefektifan proses pembelajaran, penyampaian pesan dan materi pelajaran

Pembelajaran yang merupakan proses komunikasi antara guru dengan siswa, guru sebagai penyampai informasi dan siswa sebagai penerima informasi. Dalam interaksi tersebut terjadi penyimpangan-penyimpangan dalam berkomunikasi sehingga tidak efektif dan efisien yang disebabkan adanya kecenderungan verbalisme, ketidaksiapan siswa, kurangnya minat dan kegairahan dalam belajar yang berdampak pada kejenuhan dalam belajar

Untuk menghindari kesalahan penerimaan informasi oleh siswa, maka seorang guru harus memiliki keterampilan khusus sehingga dapat melaksanakan suatu pembelajaran yang bermakna bagi siswa. Belajar bermakna merupakan suatu proses yang dapat menimbulkan perubahan perilaku kognitif, afektif, dan psikomotor pada diri siswa secara bertahap.

Media pembelajaran model mind mapping dapat diimplementasikan pada mata pelajaran Pendidikan Agama Islam materi struktur organisasi kehidupan memuat informasi yang bersifat abstrak. Dengan kata lain, penerapan media model mind mapping bertujuan untuk : (1)Lebih efektif dan efisien, (2) Ide ide baru bisa muncul dengan menggambar diagram diagram, (3)Digram yang terbentuk bisa menjadi alur berfikir yang efektif dan bermanfaat untuk hal lain.

Berdasarkan latar belakang di atas, maka pada penelitian ini peneliti memfokuskan kajian penelitian sebagai berikut :

Penelitian ini berfokus pada penggunaan media pembelajaran model simulasi dalam peningkatan proses belajar mengajar.

Penelitian ini berfokus pada peningkatan pemahaman siswa.

Penelitian terbagi ke dalam dua kelas, kelas kontrol yang pembelajarannya menggunakan metode ceramah dan kelas eksperimen kelas yang menggunakan media pembelajaran model simulasi.

\section{Rumusan Masalah}

Berdasarkan latar belakang dan batasan masalah dalam penelitian ini, maka rumusan permasalahan penelitian sebagai berikut :

1. Bagaimana efektifitas penggunaan media pembelajaran model mind mapping dibandingkan dengan kelas konvensional dalam meningkatkan pemahaman siswa pada mata pelajaran PAI?

2. Bagaimanakah tanggapan atau respon siswa terhadap penggunaan media pembelajaran model mind mapping dalam meningkatkan pemahaman siswa pada mata pelajaran PAI?

\section{Tujuan Penelitian}

Sesuai pada rumusan masalah yang ada, maka tujuan yang hendak dicapai dalam penelitian ini adalah :

1. Untuk mengetahui efektifitas penggunaan media pembelajaran model mind mapping mulasi dibandingkan dengan kelas konvensional dalam meningkatkan pemahaman siswa pada mata pelajaran PAI

2. Untuk mengetahui tanggapan peserta didik terhadap penggunaan media pembelajaran model mind mapping.

\section{Manfaat Penelitian}

1. Penelitian ini diharapkan dapat memberikan manfaat baik bagi siswa, guru, sekolah maupun institusi pendidikan lainnya.

2. Bagi siswa, melalui penelitian ini diharapkan dapat meningkatkan pemahaman siswa.

3. Bagi guru, diharapkan penelitian ini dapat:

4. Memberikan masukan mengenai strategi pembelajaran dalam upaya meningkatkan pemahaman siswa.

5. Memotivasi guru untuk melakukan model pembelajaran yang sejenis untuk semua materi pelajaran atau memotivasi guru untuk melakukan inovasi pembelajaran yang menggunakan media pembelajaran model simulasi.

\section{METODE}

Dalam penelitian ini peneliti menggunakan pendekatan kuantitatif dengan 
metode penelitian kuasi eksperimen/eksperimen semu. Eksperimen semu adalah jenis metode yang membandingkan pengaruh pemberian suatu perlakuan (Treatment) pada suatu objek (kelompok eksprimen) serta melihat besar pengaruh maupun efektivitas suatu perlakuan. Bentuik desain kuasi eksperimen merupakan pengembangan dari true experimental design

Desain penelitian yang digunakan dalam penelitian ini adalah Pretest-posttest Nonequivalent Control Group Design dimana dalam desain ini terdapat dua kelompok yaitu kelompok kontrol dan kelompok eksperimen yang tidak dipilih secara penugasan random. Pada kelas eksperimen perlakukan yang diberikan menerapkan $m$-learning sedangkan paa kelas kontrol tanpa menggunakan m-learning.

Tabel 3.1 Desain Penelitian

\begin{tabular}{|l|l|l|l|}
\hline Kelompok & Pretest & Perlakukan & Postest \\
\hline Eksperimen & O1 & X1 & O2 \\
\hline Kontrol & 03 & X2 & 04 \\
\hline
\end{tabular}

Keterangan :

$0_{1}$ : tes sebelum perlakuan

$\mathrm{O}_{3}$ : tes sebelum perlakuan

$\mathrm{O}_{2}$ : tes setelah pelakuan

$0_{4}$ : tes setelah perlakun

$\mathrm{X}_{1}$ : Penerapan Multimedia Interaktif model simulasi

$\mathrm{X}_{2}$ : Tanpa menggunakan Multimedia Interaktif model simulasi

\section{Populasi dan Sampel Penelitian}

Populasi

Populasi dalam penelitian ini adalah siswa SMA Muhammdiyah Kadungora kelas XI tahun ajaran 202/2021.

\section{Sampel}

Sampel adalah sebagian dari jumlah dan memiliki karakteristik yang ada pada populasi tersebut [10]. Adapun sampel pada penelitian ini berdasarkan pertimbangan di atas adalah dua kelas yaitu yaitu siswa kelas XI MIPA 2 sebanyak 35 siswa sebagai kelas eksperimen dan siswa kelas XI MIPA 3 Sebanyak 35 siswa sebagai kelas kontrol.

\section{Tempat dan Waktu Penelitian}

Tempat penelitian ini dilaksanakan di SMA Muhammadiyah Kadungora penelitian dilaksanakan pada waktu semester genap tahun pelajaran 2020/2021

\section{Instrument Penelitian}

Instrumen penelitian adalah suatu alat yang digunakan untuk mengukur fenomena alam maupun social yang diamati Instrument penelitian yang akan digunakan dalam penelitian ini adalah sebagai berikut:

\section{Tes Prestasi Siswa}

Tes adalah alat atau prosedur yang digunakan sebagai pengukuran atau penilaian, tes yang digunakan dalam penelitian ini berupa tes awal (pretest) dan tes akhir (posttest) dengan teknik pilihan ganda (multiple choice).

Kuesioner

Kuesioner digunakan sebagai data pendukung yang bertujuan untuk mengetahui tanggapan siswa terhadap penggunaan multimedia interaktif model mind mapping pada pembelajaran Pendidikan Agama Islam.

\section{Uji Coba Instrumen}

Instrumen penelitian dianalisis dengan teknik uji validitas, uji reliabilitas, uji tingkat kesukaran, dan daya pembeda. Berikut ini tahapan analisis indtrumen penelitian :

\section{Uji Validitas}

Validitas adalah suatu ukuran yang menunjukkan tingkat kevalidan atau keshahihan suatu instrumen. Untuk mengetahui apakah suatu instrumen dapat dijadikan sebagai alat ukur dengan tepat, maka dapat digunakan teknik korelasi.Teknik yang digunakan untuk mengetahui kesejajaran menurut adalah teknik kolerasi product moment yang dikemukakan oleh Pearson.

$$
r_{X Y}=\frac{n \sum X Y-\left(\sum X\right)\left(\sum Y\right)}{\sqrt{ }\left(n \sum X^{2}-\left(\sum X\right)^{2}\right) \cdot\left(n \sum Y^{2}-\left(\sum Y\right)^{2}\right)}
$$

Keterangan :

$\mathrm{r}_{\mathrm{XY}}=$ koefisien korelasi

$\mathrm{X}=$ skor item tes

$\mathrm{Y}=$ jumlah skor item

$\mathrm{n} \quad=$ banyaknya peserta tes

Untuk mengetahui kevalidan butir soal maka harga rhitung dibandingkan rtabel sesuai dengan jumlah responden. Jika rhitung $>$ rtabel maka butir soal tersebut dinyatakan valid. Adapun interpretasi kevalidan butir soal dapat dilihat dalam tabel interpretasi validitas butir soal Guilford (1956:145) dalam Nurcahyanto (2013:3) 


\section{Tabel 3.2 Validitas Butir Soal}

\begin{tabular}{|l|l|}
\hline Besarnya $\mathbf{r}_{\mathbf{x y}}$ & Interpretasi \\
\hline $0,80<\mathrm{r}_{\mathrm{xy}} \leq 1,00$ & Validitas sangat tinggi \\
$0,60<\mathrm{r}_{\mathrm{xy}} \leq 0,80$ & Validitas tinggi \\
$0,40<\mathrm{r}_{\mathrm{xy}} \leq 0,60$ & Validitas sedang \\
$0,20<\mathrm{r}_{\mathrm{xy}} \leq 0,30$ & Validitas rendah \\
$0,00<\mathrm{r}_{\mathrm{xy}} \leq 0,20$ & Validitas sangat \\
$\mathrm{r}_{\mathrm{xy}} \leq 0,00$ & rendah \\
& Tidak valid \\
\hline
\end{tabular}

\section{Uji Reliabilitas Instrumen}

Reliable adalah instrumen yang bila digunakan beberapa kali untuk mengukur objek yang sama, akan menghasilkan data yang sama juga, Suatu tes dapat dikatakan mempunyai taraf signifikansi tinggi apabila tes tersebut dapat memberikan hasil yang tetap dan cukup dipercaya untuk digunakan sebagai alat pengumpul data.

Teknik analisis data, untuk pengujian reliabilitas menggunakan rumus Cronbach's Alpha:

Keterangan :

$$
\mathrm{r}_{11}=\left(\frac{n}{n-1}\right)\left(1-\frac{\sum_{S i} 2}{S i^{2}}\right)
$$

$$
\begin{array}{ll}
\mathrm{r}_{11} & =\text { reliabilitas instrumen } \\
\mathrm{n} & =\text { banyaknya butir pertanyaan } \\
\sum_{\mathrm{S}_{\mathrm{i}}}{ }^{2} & =\text { jumlah varians item } \\
\mathrm{S}_{\mathrm{i}}{ }^{2} & =\text { varians total }
\end{array}
$$

Tabel 3.4. Tingkat Reliabilitas

\begin{tabular}{|l|l|}
\hline Alpha & Tingkat Reliabilitas \\
\hline $0,00 \leq \mathrm{r} 11<0,20$ & Sangat rendah \\
$0,20 \leq \mathrm{r} 11<0,40$ & Rendah Cukup Tinggi \\
$0,40 \leq \mathrm{r} 11<0,60$ & Sangat Tinggi \\
$0,60 \leq \mathrm{r} 11<0,80$ & \\
$0,80 \leq \mathrm{r} 11 \leq 1,00$ & \\
\hline
\end{tabular}

\section{Uji Taraf Kesukaran}

Kesukaran suatu butir soal adalah bilangan yang menunjukkan sukar dan mudahnya suatu soal. Besarnya indeks kesukaran antara 0,00 sampai dengan 1,0. Soal dengan indeks kesukaran 0,00 menunjukkan bahwa soal itu terlalu sukar, sedangkan indeks 1,0 menunjukkan soal itu terlalu mudah. Suatu soal tes hendaknya tidak terlalu sukar dan tidak pula terlalu mudah. Rumus yang digunakan untuk menghitung tingkat kesukaran.

$$
P=\frac{B}{J S}
$$

Keterangan :

$\mathrm{P} \quad=$ indeks tingkat kesukaran

$\mathrm{B}=$ jumlah siswa yang menjawab benar

JS = jumlah seluruh siswa peserta tes

Tabel 3.6. Klasifikasi Indeks Kesukaran

\begin{tabular}{|l|l|}
\hline Nilai Indeks Kesukaran & $\begin{array}{l}\text { Tingkat } \\
\text { Kesukaran }\end{array}$ \\
\hline $0,00<=\mathrm{P}<=0,30$ & Sukar \\
$0,31<=\mathrm{P}<=0,70$ & Sedang \\
$0,71<=\mathrm{P}<=1,00$ & Mudah \\
\hline
\end{tabular}

\section{Daya Pembeda}

Daya pembeda adalah kemampuan soal untuk membedakan antara siswa yang menguasai materi (berkemampuan tinggi) dengan siswa tidak menguasai (berkemampuan rendah) materi pelajaran (Arikunto, 2009:211). Rumus yang digunakan sebagai berikut:

$$
D=\frac{B A}{J A}-\frac{B B}{J B}=P A-P B
$$

Keterangan :

$$
\begin{aligned}
& \mathrm{D}=\text { Daya Pembeda } \\
& \mathrm{J}=\text { Banyaknya siswa } \\
& \mathrm{JA}=\text { Banyaknya siswa pada kelompok } \\
& \quad \text { atas } \\
& \mathrm{JB}=\begin{array}{c}
\text { Banyaknya siswa pada kelompok } \\
\text { bawah }
\end{array} \\
& \mathrm{BA}=\text { Banyak siswa kelompok atas yang } \\
& \text { menjawab soal dengan benar } \\
& \mathrm{BB}=\text { Banyak siswa kelompok bawah } \\
& \text { yang menjawab dengan benar }
\end{aligned}
$$

Menurut, hasil perhitungan dikonsultasikan atau disesuaikan dengan klasifikasi daya pembeda

Tabel 3.8. Klasifikasi Daya Pembeda

\begin{tabular}{|l|l|}
\hline Nilai & $\begin{array}{l}\text { Tingkat Daya } \\
\text { Pembeda }\end{array}$ \\
\hline $0,00 \leq \mathrm{D} \leq 0,20$ & jelek (poor) \\
$0,21 \leq \mathrm{D} \leq 0,40$ & cukup (satisfactory) \\
$0,41 \leq \mathrm{D} \leq 0,70$ & baik (good) \\
$0,71 \leq \mathrm{D} \leq 1,00$ & sangat baik (excellent) \\
Negative & sebaiknya dibuang saja. \\
\hline
\end{tabular}

\section{Teknik Analisis data}

menjelaskan bahwa " analisis data diarahkan untuk menjawab rumusan masalah atau menguji hipotesis yang telah dirumuskan. Dalam penelitian ini, penulis menggunakan 
teknik analisis data dengan pendekatan metode kuantitatif deskriptif. Dimana dalam pengolahan data secara kuantitatif ini mengolah data hasil pretest dan posttest. Adapun langkahlangkah pengolahan datanya sebagai berikut :

\section{Pemberian Skor}

Skor untuk soal pilihan ganda ditentukan berdasarkan metode Right Only, yaitu jawaban benar diberi skor satu dan jawaban salah atau butir soal yang tidak dijawab diberi skor nol.

\section{Pengolahan data skor pretest dan posttest} pemahaman matematis

Pengolahan data skor hasil pretest dan posttest dianalisis dengan langkah sebagai berikut :

Menghitung nilai rata-rata kelompok, minimum maksimum, standar deviasi dan varians dengan menggunakan program SPSS 20.0 for Windows

Melakukan uji normalitas. Uji ini dilakukan untuk mengetahui apakah data dari masing-masing kelompok sampel berdistribusi normal atau tidak. Pengujian normalitas sebaran data dilakukan dengan cara membandingkan nilai Kolmogorov-Smirnov dan Probabilitas dengan nilai signifikansinya adalah 0,05 .

Dengan dasar pengambilan keputusan bahwa :

$\mathrm{P}$ dari koefisien K-S $>\alpha(0,05)$, maka data berdistribusi normal

$\mathrm{P}$ dari koefisien $\mathrm{K}-\mathrm{S}<\alpha(0,05)$, maka data tidak berdistribusi normal. Perhitungan dalam pengujian normalitas sebaran data ini menggunakan program SPSS 20.0 for Windows

Melakukan uji homogenitas. Uji ini dilakukan untuk mengetahui apakah data dari masing-masing kelompok sampel mempunyai varians yang sama atau berbeda. Untuk menguji homogenitas digunakan uji Levene dengan taraf signifikansi 5\% dengan menggunakan program SPSS 20.0 for Windows

Kriteria pengujian :

Jika nilai signifikansi $\mathrm{P}>\alpha(0.05)$, maka homoge.

Jika nilai signifikansi $\mathrm{P}<\propto(0.05)$, maka tidak homogen

Jika Melakukan uji kesamaan dua rata-

rata. Uji kesamaan dilakukan untuk mengetahui apakah terdapat kesamaan antara rata-rata nilai pretest perolehan dari kelas kontrol dan kelas eksperimen sebelum dilakukan pembelajaran. Uji ini dilakukan jika data berdistribusi normal dan homogen, maka dilakukan uji t dengan bantuan program SPSS 20.0, dengan taraf signifikansi 5\%.

Jika data berdistribusi normal dan homogen, maka digunakan uji $t$ dengan statistik Independent Sample T-Test menggunakan equal varianced assumsed

Jika data berdistribusi normal dan tidak homogen, maka digunakan uji t' dengan statistik Independent Sample T-Test menggunakan equal variances not assumed.

Jika data tidak berdistribusi normal atau salah satu dari kedua data tersebut tidak berdistribusi normal dan homogen, maka digunakan uji statistik non-parametrik MannWhitney

Pengujian hipotesis dan hasilnya akan digunakan sebagai acuan penarikan kesimpulan. Kriteria Uji :

Independent Sample T-Test :

Jika $\mathrm{t}_{\text {hitung }} \leq \mathrm{t}_{\text {tabel, }}$, maka $\mathrm{H}_{0}$ diterima

Jika thitung $\geq t_{\text {tabel}}$, maka $\mathrm{H}_{0}$ ditolak

Berdasarkan signifikansi :

Jika signifikansi $(\mathrm{P})<0,05$, maka $\mathrm{H}_{0}$ ditolak Jika signifikansi $(\mathrm{P})>0,05$, maka $\mathrm{H}_{0}$ diterima

Mann-Whitney

Jika signifikansi $(\mathrm{P})<0.05$, maka $H_{0}$ ditolak

Jika signifikansi $(\mathrm{P})>0.05$, maka $H_{0}$ diterima

\section{Analisis Data Indeks Gain}

Gain adalah selisih antara nilai posttest dan pretest. Gain menunjukkan peningkatan minat dan pemahaman atau penguasaan konsep mahasiswa setelah proses pembelajaran. Besar gain yang ternormalisasi ini diinterpretasikan untuk menyatakan kriteria gain ternormalisasi :

Gain ternormalisasi $(N$-gain $)=$ skor postes-skor pretes

skor ideal-skor pretes

Dengan kategori gain ternormalisasi (g) sebagai berikut : 
Tabel 3.13. Nilai Gain

\begin{tabular}{|l|l|}
\hline \multicolumn{1}{|c|}{ NilAI $\boldsymbol{g}$} & \multicolumn{1}{c|}{ Interpretasi } \\
\hline $0.7<g<1$ & Tinggi \\
\hline $0.3 \leq g \leq 0.7$ & Sedang \\
\hline $0<g<0.3$ & Rendah \\
\hline
\end{tabular}

\section{HASIL PENELITIAN}

Hasil penelitian menunjukkan bahwa pertama metode pembelajaran mind mapping dapat meningkatkan kemampuan hasil belajar matematis siswa, kedua penggunaan multimedia interaktif dapat meningkatkan kemampuan hasil belajar matematis siswa, ketiga pembelajaran metode mind mapping dan penggunaan multimedia dapat meningkatkan kemampuan hasil belajar siswa. Hal ini ditandai dengan hasil penelitian pada mata pelajaran Matematika kompetensi dasar Bangun datar segitiga di kelas XI SMA Muhammadiyah Kadungora tahun ajaran 2020/2021 bahwa hasil Pendidikan Agama Islam siswa mengalami peningkatan dimana skor rata-rata pembelajaran tanpa multimedia $69,4 \%$ dan skor rata-rata pembelajaran menggunakan multimedia adalah $79,6 \%$.

\section{KESIMPULAN}

Berdasarkan hasil penelitian yang diperoleh selama melaksanakan kegiatan penelitian tentang penggunaan Model Pembelajaran metode mind mapping dengan multimedia interaktif untuk meningkatkan hasil belajar siwa pada Pelaksanaan Pengurusan Jenazah di SMA Muhammadiyah Kadungora tahun ajaran 2020/2021, diperoleh beberapa kesimpulan sebagai berikut:

Penggunaan Model Pembelajaran metode mind mapping dengan multimedia dapat meningkatkan kemampuan hasil belajar pendidikan agama islam peserta didik. Hal ini ditandai dengan hasil penelitian pada mata pelajaran pendidikan agama islam kompetensi pelaksanaan pengurusan jenazah di SMA Muhammadiyah tahun ajaran 2020/2021 bahwa hasil belajar siswa ada perbedaan, dimana skor rata-rata pembelajaran menggunakan media adalah $79,6 \%$.

Penggunaan Model Pembelajaran metode mind mapping tanpa multimedia kurang meningkatkan kemampuan hasil belajar pendidikan agama islam peserta didik. Hal ini ditandai dengan hasil penelitian pada mata pelajaran pendidikan matematika kompetensi dasar pelaksanaan pengurusan jenazah SMA Muhammadiyah Kadungora tahun ajaran 2020/2021 bahwa hasil belajar siswa ada perbedaan, dimana skor rata- rata pembelajaran tanpa media adalah 69,4\%.

Hasil belajar siswa yang memperoleh pembelajaran dengan menggunakan metode mind mapping dan miltimedia lebih baik dari siswa yang memperoleh pembelajaran metode mind mapping tanpa multimedia dilihat dari nilai rata-rata kelas eksperimen adalah 11,94 dan kelas control adalah 10,41.

\section{DAFTAR PUSTAKA}

G. N. W. Astra, I. M. Suarjana, and I. I. W. Suwatra, "Pengaruh model pembelajaran problem solving berbantuan media video pembelajaran matematika terhadap kemampuan pemecahan masalah siswa IV gugus IV kecamatan Sukasada," J. Mimb. PGSD Univ. Pendidik. Ganesha, vol. 1, no. 1, 2013, [Online]. Available: https://ejournal.undiksha.ac.id/index.ph p/JJPGSD/article/view/1399/1260.

S. Smith, K. Maund, T. Hilaire, T. Gajendran, J. Lyneham, and S. Geale, "Enhancing discipline specific skills using a virtual environment built with gaming technology," Int. J. Work. Learn., vol. 21, no. 3, pp. 211-222, 2020.

C. A. Talib, H. Aliyu, A. M. A. Malik, K. H. Siang, I. Novopashenny, and M. Ali, "Sakai: A mobile learning platform," Int. J. Interact. Mob. Technol., vol. 13, no. 11, pp. 95-110, 2019, doi: 10.3991/ijim.v13i11.10800.

Munir, "Multimedia (Konsep \& Aplikasi dalam Pendidikan,” p. 2015, 2015.

S. H. Mun et al., "Active learning using digital smart board to enhance primary school students' learning," Int. J. Interact. Mob. Technol., vol. 13, no. 7, pp. 4-16, 2019, doi: 10.3991/ijim.v13i07.10654.

M. A. Ahmad Munjin Nasih, S.Pd. and M. P. I. Lilik Nur Kholidah, S, Pd., "Metode 
Dan Teknik Pembelajaran Pendidikan Agama Islam," pp. 15-34, 2009, [Online]. Available: http://etheses.uinmalang.ac.id/1514/6/11410038_Bab_2. pdf.

W. M. Daher and N. F. Baya'a, "Learning Mathematics in an Authentic Mobile Environment: the Perceptions of Students," Int. J. Interact. Mob. Technol., vol. 3, no. 0, pp. 6-14, 2009, doi: 10.3991/ijim.v3s1.813.

K. Reinhard and A. Gerloff, "Internationalizing cooperative education: Implementing the German DHBW model in Thailand and China," Int. J. Work. Learn., vol. 21, no. 3, pp. 289-301, 2020.

J. Bidarra, M. Figueiredo, and C. Natálio, "Interactive design and gamification of ebooks for mobile and contextual learning," Int. J. Interact. Mob. Technol., vol. 9, no. 3, pp. 24-32, 2015, doi: 10.3991/ijim.v9i3.4421.

Sugiyono, Metode Penelitian Kuantitatif, Kualitatif. Bandung, 2012.

Arikunto, "Arikunto, Suharsimi. 2006. Prosedur Penelitian Suatu Pendekatan Praktik.," Jakarta PT. Asdi Mahasatya., p. 2006, 2006.

R. Sundaya, Statistika Penelitian Pendidikan. Garut: STKIP Garut.

S. Arikunto, Prosedur Penelitian Suatu Pendekatan Praktik, Rineka Cip. Jakarta, 2010. 